\title{
Knowing biodiversity: Fishes from the Guareí River basin, a tributary of the Jurumirim reservoir, Paranapanema River, Brazil
}

\author{
Valter M. Azevedo-Santos ${ }^{I *}$, Fernando M. Pelicice ${ }^{2} \mathbb{Q}^{\mathbb{Q}}$ Raoul Henry $^{I}(\mathbb{C}$ \\ ${ }^{1}$ Universidade Estadual Paulista, Instituto de Biociências, Botucatu, SP, Brasil. \\ ${ }^{2}$ Universidade Federal do Tocantins, Núcleo de Estudos Ambientais, Porto Nacional, TO, Brasil. \\ *Corresponding author: Valter M. Azevedo-Santos, e-mail: valter.ecologia@gmail.com
}

\begin{abstract}
AZEVEDO-SANTOS, V.M., PELICICE, F.M., HENRY, R. Knowing biodiversity: Fishes from the Guareí River basin, a tributary of the Jurumirim reservoir, Paranapanema River, Brazil. Biota Neotropica 20 (3): e20201031. https://doi.org/10.1590/1676-0611-BN-2020-1031
\end{abstract}

\begin{abstract}
The Guareí River is a tributary of the Paranapanema River (Brazil), located in the upper portion of the Jurumirim Reservoir. Fish fauna studies in this watershed began in the 2000s, but they were restricted to a few waterbodies. This work conducted a broad survey of the fish fauna in tributary streams and the main channel of the Guareí River. Sampling occurred between February 2017 and November 2018 at 36 sites and using different collection methods. We captured 2,169 specimens belonging to 50 species, 16 families and 6 orders. The species accumulation curve tended to stabilize but indicated that species richness is underestimated. Almost all species are native (46); only three were non-native (Hyphessobrycon eques, Oreochromis niloticus and Poecilia reticulata) and one was undefined (Gymnotus pantanal). Among the native species, two are unknown to science (Bryconamericus aff. iheringii and Hypostomus sp. n.) and three are migratory (Leporinus friderici, Megaleporinus obtusidens and Pimelodus maculatus). In this paper, we provide images of species collected. Results indicate that the Guareí River basin is a hotspot of fish diversity in the Upper Paranapanema River, stressing the need for adequate management and conservation actions.
\end{abstract}

Keywords: Inventory; migratory fish; non-native fish; Paraná River basin; stream; undescribed species.

\section{Conhecendo a biodiversidade: Peixes da bacia do Rio Guareí, um afluente do reservatório de Jurumirim, Rio Paranapanema, Brasil}

Resumo: O Rio Guareí é um afluente do Rio Paranapanema (Brasil), localizado na parte superior do reservatório de Jurumirim. Os estudos da fauna de peixes nesta bacia hidrográfica começaram nos anos 2000, mas estão restritos a poucos corpos d'água. Este trabalho realizou um amplo levantamento da ictiofauna em tributários e no canal principal do Rio Guareí. As amostragens ocorreram entre Fevereiro de 2017 e Novembro de 2018 em 36 sítios e utilizando diferentes métodos de coleta. Capturamos 2.169 espécimes pertencentes a 50 espécies, 16 famílias e 6 ordens. A curva de acumulação de espécies tendeu a se estabilizar, mas indicou que a riqueza de espécies está subestimada. Quase todas as espécies são nativas (46); apenas três não nativas (Hyphessobrycon eques, Oreochromis niloticus, e Poecilia reticulata) e uma não definida (Gymnotus pantanal). Entre as espécies nativas, duas são desconhecidas da ciência (Bryconamericus aff. iheringii e Hypostomus sp. n.) e três migradoras (Leporinus friderici, Megaleporinus obtusidens e Pimelodus maculatus). Neste artigo, fornecemos imagens das espécies coletadas. Os resultados indicam que a bacia do Rio Guareí é uma região importante em termos de diversidade de peixes no alto Rio Paranapanema, enfatizando a necessidade de ações adequadas de manejo e conservação.

Palavras-chave: Bacia do Rio Paraná; espécies não descritas; inventário; peixe migrador; peixes não nativos; riacho. 


\section{Introduction}

The diversity of freshwater fishes in Brazil ( $>3,000$ species; ICMBio 2018) is higher than in any other Neotropical country (e.g., Litz \& Koerber 2014; Mirande \& Koerber 2015; DoNascimiento et al. 2017). In part, the high diversity is related to the presence of the Amazon basin, a megadiverse region (Dagosta \& de Pinna 2019). However, other important river systems hold remarkable biodiversity, such as the Upper Paraná River (Langeani et al. 2007; Ota et al. 2018). This basin sums more than three hundred species, with dozens still undescribed (Langeani et al. 2007).

In the last century, numerous studies about fish composition, biology, ecology, taxonomy have been carried out in the Upper Paraná River (e.g., Agostinho \& Júlio-Jr. 1999; Britto \& Carvalho 2006; Brandão et al. 2009; Dias \& Tejerina-Garro 2010; Esguícero \& Arcifa 2011; Cionek et al. 2012; Carvalho \& Langeani 2013; Santos et al. 2017; Frota et al. 2020), and this basin is possibly the most studied in Brazil. However, several questions remain open, including total diversity, biogeographic patterns and ecological aspects, demanding further studies. The occurrence of Phenacorhamdia tenebrosa (Schubart, 1964) on the Upper Paraná River is a good example: although this fish was recorded by several studies (e.g., Schubart 1964; Manoel \& Uieda 2018; Cavalli et al. 2018; Vicentin et al. 2019), more detailed information on its distribution is lacking. Perhaps more important is the fact that several waterbodies remain uninvestigated, especially small and mid-size water courses, which may harbor species unknown (i.e., undescribed) to science (Langeani et al. 2007).

If the Upper Paraná River is the most studied, it is also the most disturbed (Agostinho et al. 2007). Urbanization, agriculture, invasive species and hydrological alterations related to human activities have caused significant perturbations to fish diversity. The construction of hydropower dams, in particular, has played a central role inducing habitat alterations and biodiversity losses (Agostinho et al. 2008; Pelicice et al. 2017). For instance, the main tributaries of the basin, such as the Tietê, Grande and Paranapanema rivers, are regulated by cascade of dams (Petesse \& Petrere Jr. 2012; Loures \& Pompeu 2018; Pelicice et al. 2018), blocking migratory dynamics and affecting population recruitment (Pelicice \& Agostinho 2008). Ichthyological surveys remain incomplete in these highly disturbed systems, and once conservation initiatives rely mainly on those data (Azevedo-Santos et al. 2019), more research is needed to provide basic information in these impacted waterbodies.

Tributaries play important roles in impounded areas (Nunes et al. 2015; Silva et al. 2015; Marques et al. 2018), since they preserve fluvial conditions and a natural or semi-natural flow regime, reducing the impacts on the environment and biodiversity. The presence of tributaries may explain the maintenance of fish diversity in impounded areas, because reservoirs impose serious constraints to fish recruitment (Agostinho et al. 2008). Some studies in the Paranapanema River have pointed to the importance of tributaries (e.g., Hoffmann et al. 2005; Pelicice \& Agostinho 2008).
The Jurumirim Reservoir, in particular, has been investigated by multiple studies concerning its aquatic fauna (e.g., Panarelli et al. 2001; Sartori et al. 2009), including fish (e.g., Castro et al. 2003a; Lima et al. 2016; Lima et al. 2018; Queiroz-Sousa et al. 2019). Some studies (e.g., Seabra et al. 2012; Nobile et al. 2019) provided information about fishes in tributaries that flow into the Jurumirim Reservoir, such as the Taquarí and Guareí rivers.

The Guareí River has its mouth near the confluence between the Paranapanema River and the Jurumirim Reservoir (Leite et al. 2012). Few ichthyological studies have been conducted in this basin, and they have only investigated small watercourses (e.g., Castro et al. 2003b), lagoons (Seabra et al. 2012), population biology of two catfish species (Azevedo-Santos et al. 2018), and species description (Katz \& Costa 2020), with no estimate of total diversity in the whole basin. Despite those studies, many tributary streams, as well as the Guareí River main channel, remain uninvestigated. In this sense, here we provide a broad survey of the fish species in the Guarei River basin, with the objective to provide the first report on fish diversity in this basin.

\section{Material and Methods}

\section{Study area}

The Guareí River is a tributary of the Paranapanema River, that flows into the upper section of the Jurumirim Reservoir (Leite et al. 2012). Its drainage catchment is entirely located in the State of São Paulo (Brazil), and covers the municipalities of Guareí, in the upper course, and Angatuba in the middle and lower portions (Fulan et al. 2012).

The drainage area is about 70,860 ha (Leite et al. 2012). Many tributary streams had their vegetation totally or partially removed, a trend observed in the whole basin. At the end of the last century, the Guareí River basin was composed mostly of pasture $(>50 \%)$ and recovered vegetation $(\sim 11 \%)$ (Henry \& Gouveia 1993$)$, with fragments of Mata Atlântica and Cerrado vegetation.

\section{Methodology}

We sampled fish between February 2017 and November 2018 (Table 1), under license number 57047 (SISBIO). We sampled the Guareí River main channel and more than 20 tributary streams of different orders (Figure 1), totaling 36 sites (i.e., channel segments) across the basin. We sampled more than one site in the Guareí River and in some of its main tributaries (e.g., Guarda-Mor stream) (Table 1).

Sampling in streams was carried out with a hand net (mesh $\sim 1.5 \mathrm{~mm}$ ), and when possible, cast net (mesh $14 \mathrm{~mm}$ ) and two gill nets (mesh 10 $\mathrm{mm}$ and $20 \mathrm{~mm}$ ) were employed. In streams, the hand net was operated in 50-100 m segments always in the upstream direction, during the day (between 7:00 am and 6:00 pm). In the Guareí River channel we employed gill nets with 30, 40, 50, 60, 70, 80 and $100 \mathrm{~mm}$ mesh size, which remained deployed overnight ( $\sim 12$ hours soak time). In addition, a castnet (mesh of $14 \mathrm{~mm}$ ) and a hand net (mesh about $1.5 \mathrm{~mm}$ ) were used, both methods directed to sample areas close to the margin. 
Table 1. Information about the sites sampled across the Guareí River basin, Paranapanema River basin, São Paulo, Brazil.

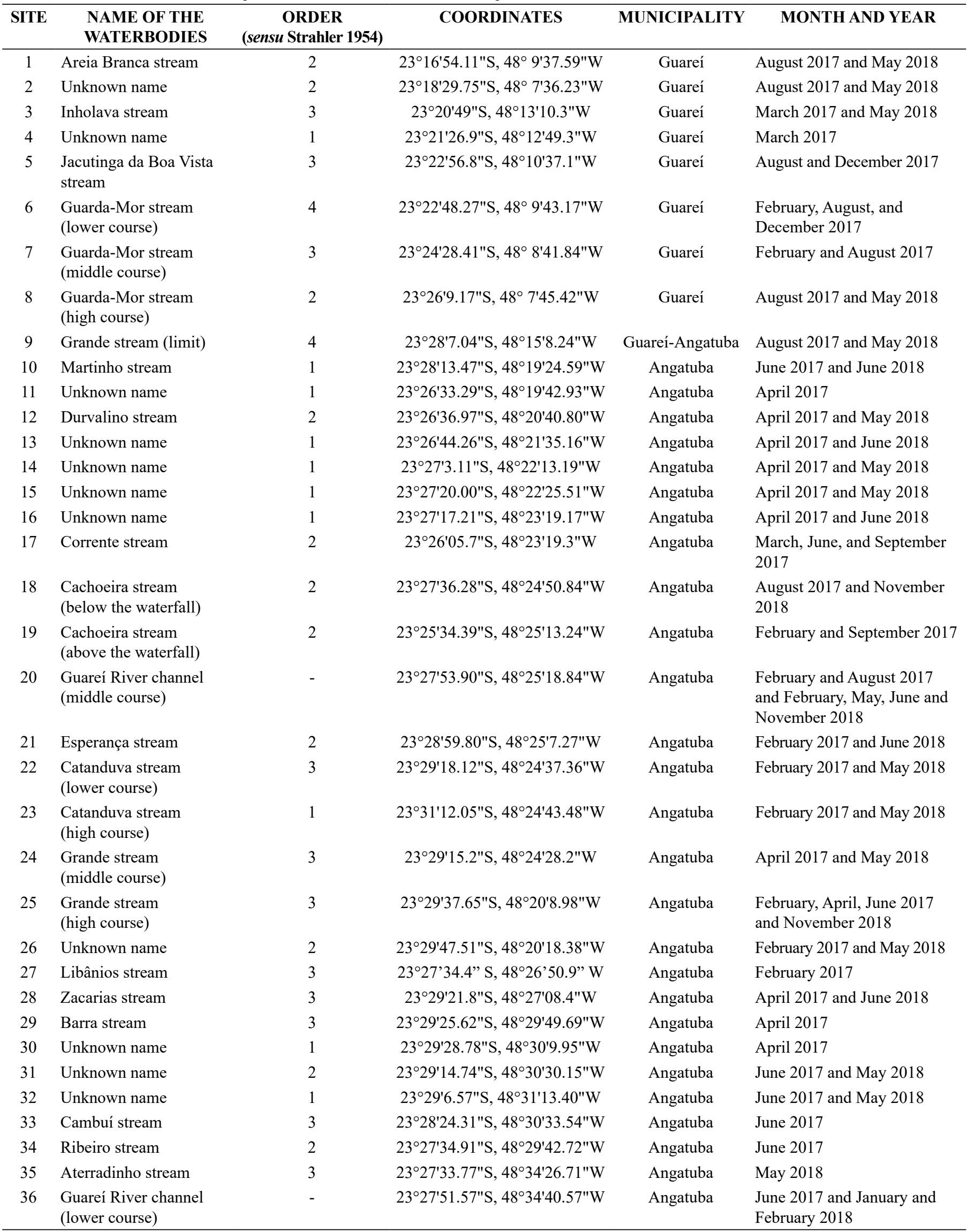




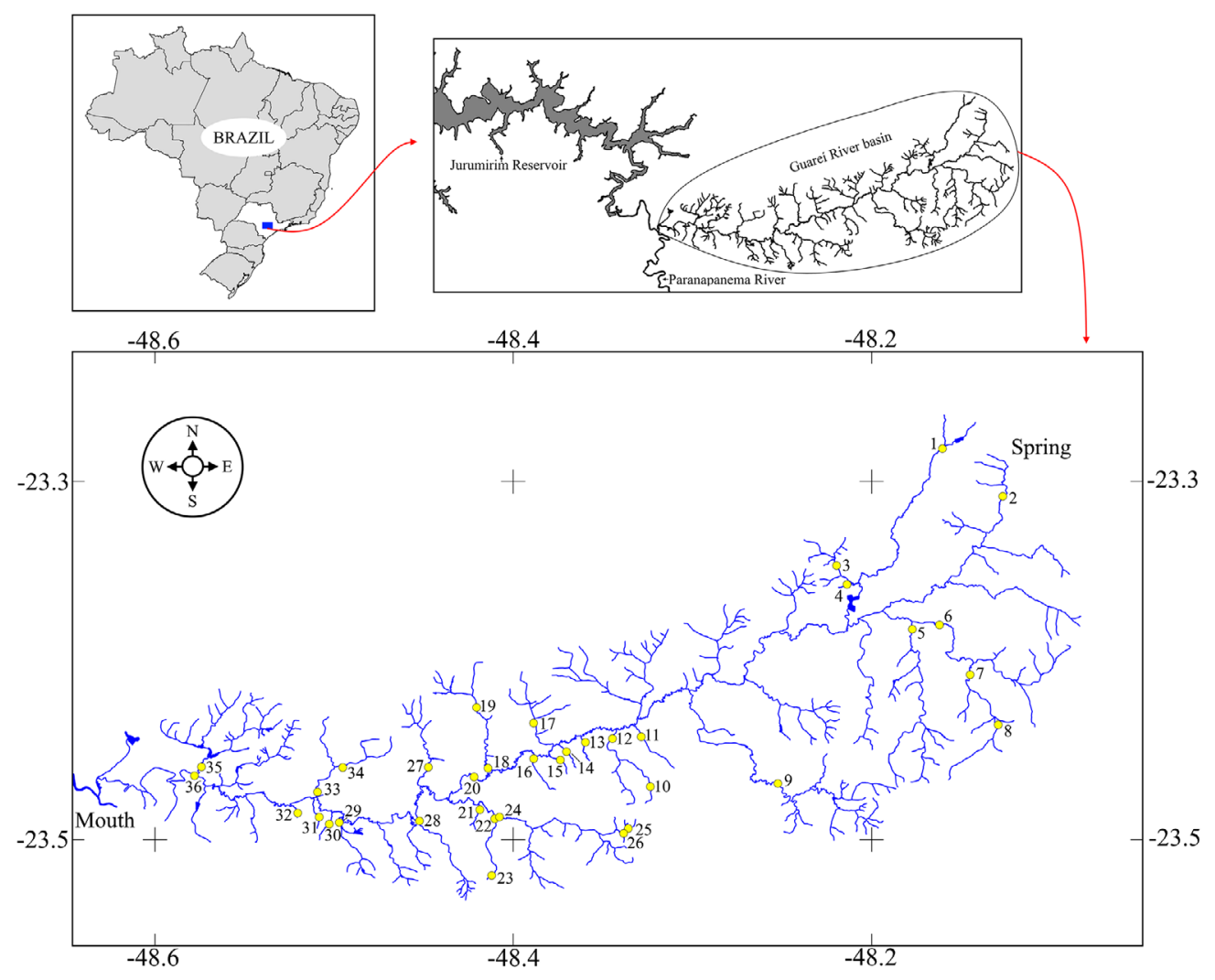

Figure 1. Guareí River basin and the location (yellow circles) of sampled sites (1 to 36). The map was drawn in the Software QGis (Sherman et al. 2012).

In the field, fishes were euthanized with a solution of water and eugenol or benzocaine (lethal dosage), and then preserved in formalin $(10 \%)$. Voucher specimens were prepared (washed with water and transferred to $70 \%$ alcohol) and deposited in the following Brazilian biological collections: DZSJRP - Departamento de Zoologia e Botânica, Universidade Estadual Paulista "Júlio de Mesquita Filho" (UNESP), Campus de São José do Rio Preto, São Paulo; LBP - Laboratório de Biologia e Genética de Peixes, Universidade Estadual Paulista "Júlio de Mesquita Filho", Campus de Botucatu, São Paulo; LIRP - Laboratório de Ictiologia de Ribeirão Preto, Universidade de São Paulo, Ribeirão Preto, São Paulo; MNRJ - Museu Nacional, Universidade Federal do Rio de Janeiro, Rio de Janeiro, Rio de Janeiro; NUP - Coleção Ictiológica do Núcleo de Pesquisas em Limnologia, Ictiologia e Aquicultura (Nupélia), Universidade Estadual de Maringá, Maringá, Paraná; UFRGS - Universidade Federal do Rio Grande do Sul, Porto Alegre, Rio Grande do Sul; UNT - Universidade Federal do Tocantins, Porto Nacional, Tocantins. Taxonomic classification followed Fricke et al. (2020a) for families, and Fricke et al. (2020b) for orders.

A rarefaction curve was calculated considering all species captured in the 36 sampled sites (based on Table S1 and Table S2). The figure was drawn in PRIMER 6 (Clarke \& Warwick 2001).

\section{Results}

We captured 2,169 individuals belonging to 50 species in the Guareí River basin (Table 2; Figure 2 to Figure 6). The rarefaction curve for the studied area tended to stabilize, but the asymptote was not reached (Figure 7). These fishes belonged to 6 orders and 16 families, being
Characiformes the most diverse, with $48 \%$ of all species (Figure 8). Characidae was the most diverse family (24\%), followed by Loricariidae (14\%) and Heptapteridae (12\%) (Figure 9). Families with the lowest number of specie (with $2 \%$ each one) were Erythrinidae, Serrasalmidae, Trichomycteridae and Synbranchidae (Figure 9).

Local richness in each site ranged between 1 to 25 species. Sites 20 and 36, located in the Guareí River main channel, had 25 and 21 species respectively. Total abundance within sites ranged from 1 to 283 individuals (Table S1 e Table S2).

Astyanax lacustris (Lütken 1875) [Figure 3(e) and Figure S1(d)], a characid, was widely distributed in the studied area, in 21 sites. Other common species were Psalidodon fasciatus (Cuvier 1819), found in 19 sites, and the catfish Imparfinis mirini Haseman 1911, present in 16 sites. The poecilid, Phalloceros harpagos Lucinda 2008, was the most abundant, with 253 individuals (Table 2), while Leporinus friderici (Bloch 1794), L. striatus Kner 1858, Pimelodella gracilis (Valenciennes 1835) and Synbranchus marmoratus Bloch 1795 were rare, with one individual each species.

Three species were non-native to the Guareí River basin, Hyphessobrycon eques (Steindachner 1882), Oreochromis niloticus (Linnaeus 1758) and Poecilia reticulata Peters 1859 . Non-native species showed narrow distribution, being $H$. eques collected only in site $32, O$. niloticus in site 29, and P. reticulata in sites 21 and 22, both located in the urban perimeter of the municipality of Angatuba. In general, non-natives were not abundant, excepting $P$. reticulata (cf. Table 2). The native status of Gymnotus pantanal Fernandes, Albert, Daniel-Silva, Lopes, Crampton, \& Almeida-Toledo 2005, was uncertain (see Discussion section). 
Table 2. Species (Actinopterygii) recorded in the Guareí River basin, Paranapanema River basin, São Paulo, Brazil.

\begin{tabular}{|c|c|c|c|}
\hline SPECIES & ABUNDANCE & STATUS & VOUCHER \\
\hline \multicolumn{4}{|l|}{ CHARACIFORMES } \\
\hline \multicolumn{4}{|l|}{ Crenuchidae } \\
\hline Characidium gomesi Travassos 1956 & 90 & Native & MNRJ 50435 \\
\hline Characidium zebra Eigenmann 1909 & 7 & Native & LBP 29211 \\
\hline \multicolumn{4}{|l|}{ Erythrinidae } \\
\hline Hoplias malabaricus (Bloch 1794) & 15 & Native & LBP 29218 \\
\hline Apareiodon affinis (Steindachner 1879) & 12 & Native & LBP 29223 \\
\hline Parodon nasus Kner 1859 & 10 & Native & LBP 29231 \\
\hline \multicolumn{4}{|l|}{ Serrasalmidae } \\
\hline Serrasalmus maculatus Kner 1858 & 6 & Native & LBP 29230 \\
\hline \multicolumn{4}{|l|}{ Anostomidae } \\
\hline \multicolumn{4}{|l|}{ Curimatidae } \\
\hline Cyphocharax modestus (Fernández-Yépez 1948) & 56 & Native & LBP 29228 \\
\hline Steindachnerina insculpta (Fernández-Yépez 1948) & 33 & Native & LBP 29221 \\
\hline \multicolumn{4}{|l|}{ Characidae } \\
\hline Astyanax lacustris (Lütken 1875) & 221 & Native & DZSJRP 22817 \\
\hline Bryconamericus aff. iheringii (Boulenger 1887) & 148 & Native & DZSJRP 22812 \\
\hline 'Cheirodon' stenodon Eigenmann 1915 & 23 & Native & UFRGS 28084 \\
\hline Galeocharax gulo (Cope 1870) & 8 & Native & LBP 29229 \\
\hline Hyphessobrycon eques (Steindachner 1882) & 3 & Non-Native & LBP 29219 \\
\hline Oligosarcus paranensis Menezes \& Géry 1983 & 6 & Native & DZSJRP 22816 \\
\hline \multicolumn{4}{|l|}{ GYMNOTIFORMES } \\
\hline \multicolumn{4}{|l|}{ Gymnotidae } \\
\hline Gymnotus carapo Linnaeus 1758 & 6 & Native & LBP 29209 \\
\hline $\begin{array}{l}\text { Gymnotus pantanal Fernandes, Albert, Daniel-Silva, Lopes, } \\
\text { Crampton \& Almeida-Toledo } 2005\end{array}$ & 5 & Indeterminate & LBP 29210 \\
\hline \multicolumn{4}{|l|}{ SILURIFORMES } \\
\hline \multicolumn{4}{|l|}{ Trichomycteridae } \\
\hline Cambeva guareiensis Katz \& Costa 2020 & 71 & Native & DZSJRP 22781 \\
\hline \multicolumn{4}{|l|}{ Callichthyidae } \\
\hline Callichthys callichthys (Linnaeus 1758) & 12 & Native & LBP 29216 \\
\hline Hoplosternum littorale (Hancock 1828) & 5 & Native & LBP 29215 \\
\hline \multicolumn{4}{|l|}{ Loricariidae } \\
\hline Hisonotus depressicauda (Miranda Ribeiro 1918) & 26 & Native & DZSJRP 22749 \\
\hline Hypostomus ancistroides (Ihering 1911) & 26 & Native & NUP 22311 \\
\hline Hypostomus iheringii (Regan, 1908) & 62 & Native & LBP 29213 \\
\hline Hypostomus sp. n. & 57 & Native & NUP 22310 \\
\hline Hypostomus tietensis (Ihering 1905) & 2 & Native & LBP 29212 \\
\hline Hypostomus strigaticeps (Regan 1908) & 63 & Native & NUP 22312 \\
\hline Rineloricaria pentamaculata Langeani \& de Araujo 1994 & 7 & Native & DZSJRP 22834 \\
\hline
\end{tabular}




\begin{tabular}{|c|c|c|c|}
\hline \multicolumn{4}{|l|}{ Heptapteridae } \\
\hline Imparfinis borodini Mees \& Cala 1989 & 9 & Native & DZSJRP 22741 \\
\hline Imparfinis mirini Haseman 1911 & 111 & Native & LIRP 14330 \\
\hline Phenacorhamdia tenebrosa (Schubart 1964) & 35 & Native & DZSJRP 22752 \\
\hline Pimelodella avanhandavae Eigenmann 1917 & 37 & Native & LBP 29226 \\
\hline Pimelodella gracilis (Valenciennes 1835) & 1 & Native & LIRP 14328 \\
\hline Rhamdia quelen (Quoy \& Gaimard 1824) & 9 & Native & DZSJRP 22751 \\
\hline \multicolumn{4}{|l|}{ Pimelodidae } \\
\hline Iheringichthys labrosus (Lütken 1874) & 4 & Native & LBP 29225 \\
\hline Pimelodus maculatus Lacepède 1803 & 7 & Native & LBP 29224 \\
\hline \multicolumn{4}{|l|}{ SYNBRANCHIFORMES } \\
\hline \multicolumn{4}{|l|}{ Synbranchidae } \\
\hline Synbranchus marmoratus Bloch 1795 & 1 & Native & DZSJRP 22827 \\
\hline \multicolumn{4}{|l|}{ CICHLIFORMES } \\
\hline \multicolumn{4}{|l|}{ Cichlidae } \\
\hline Geophagus brasiliensis (Quoy \& Gaimard 1824) & 60 & Native & DZSJRP 22789 \\
\hline Oreochromis niloticus (Linnaeus 1758) & 20 & Non-Native & LBP 29217 \\
\hline \multicolumn{4}{|l|}{ CYPRINODONTIFORMES } \\
\hline \multicolumn{4}{|l|}{ Poeciliidae } \\
\hline Phalloceros harpagos Lucinda 2008 & 253 & Native & UNT 016904 \\
\hline Phalloceros reisi Lucinda 2008 & 129 & Native & UNT 16404 \\
\hline Poecilia reticulata Peters 1859 & 78 & Non-Native & DZSJRP 22765 \\
\hline
\end{tabular}

We collected two undescribed species, Bryconamericus aff. iheringii (Boulenger 1887) and Hypostomus sp. n. The first was widely distributed, while the second was recorded in the Guareí River and one stream (Table S1 and Table S2).

\section{Discussion}

This study recorded 50 fish species in the Guareí River basin. However, because the accumulation curve did not stabilize, other species may be found with further sampling effort. The Guareí River basin holds $\sim 22 \%$ of all species richness known to the Paranapanema River basin (sensu Jarduli et al. 2020), an expressive value considering the relative small size of this catchment ( $\sim 70.9$ thousand ha; Leite et al. 2012). Moreover, the Guareí River basin hold ca. $16 \%$ of all species richness of the entire Upper Paraná River system (based on Langeani et al. 2007). These numbers and comparisons clearly indicate the importance of this tributary for the maintenance of fish diversity at multiple spatial scales (e.g., Guareí, Paranapanema and Paraná rivers). As a hotspot of fish diversity in the Upper Paranapanema River, the Guareí River basin needs adequate management and conservation actions to preserve its environmental integrity.

Characiformes and Siluriformes represented $84 \%$ of all species. Jarduli et al. (2020) asserted that these orders sum more than $70 \%$ of all species in the Paranapanema River basin. In the Guareí River basin, however, Characiformes dominated over Siluriformes, differing from the pattern observed in the Paranapanema River basin (sensu Jarduli et al. 2020). Characidae was the most diverse family in the studied area (24\% of all species), followed by Loricariidae (14\%). Cetra et al. (2016), studying streams in the Upper Paranapanema, found similar patterns, while Jarduli et al. (2020) recorded that both families hold $32 \%$ of all species in the Paranapanema River basin.

Almost all species (=46) are native to the Guareí River basin; only three were non-native and one indeterminate. This is an atypical trend in the Upper Paraná River, particularly the Paranapanema River, where several non-native species have been introduced (Garcia et al. 2018; Pelicice et al. 2018). The number of non-native species is also low when compared with areas close to the Guareí River basin, such as the Jurumirim Reservoir (Kurchevski \& Carvalho 2014) and a tributary, the Taquari River (Nobile et al. 2017; Nobile et al. 2019).

The three non-native species are Hyphessobrycon eques, Oreochromis niloticus and Poecilia reticulata. Castro et al. (2003b) had previously registered $O$. niloticus in the Guareí River basin. Tilapias regularly escape from fish farms (Orsi \& Agostinho 1999; Azevedo-Santos et al. 2011; Casimiro et al. 2018), and a fish farm is located upstream from the site where $O$. niloticus was collected. The characid H. eques is widely distributed in the Upper Paraná River, and some authors suggest that it is native to this watershed (Langeani et al. 2007). However, numerous other studies indicate that the species was introduced into the Paranapanema River basin (e.g., Kurchevski \& Carvalho 2014; Vidotto-Magnoni et al. 2015; Pelicice et al. 2018; Jarduli et al. 2020). We agree that it is non-native to the Guareí River basin. Poecilia reticulata is widespread in southeastern Brazil (Dias et al. 2020), including the Upper Paraná basin (e.g., Araújo et al. 2011; Cunico et al. 2019; Pagotto et al. 2012; Alves et al. 2016). In our study, this fish was captured in sites with urban impact, within the city of Angatuba. Mosquito control is probably the cause of its introduction, as this species has been commonly used to control Aedes populations (Azevedo-Santos et al. 2016). 


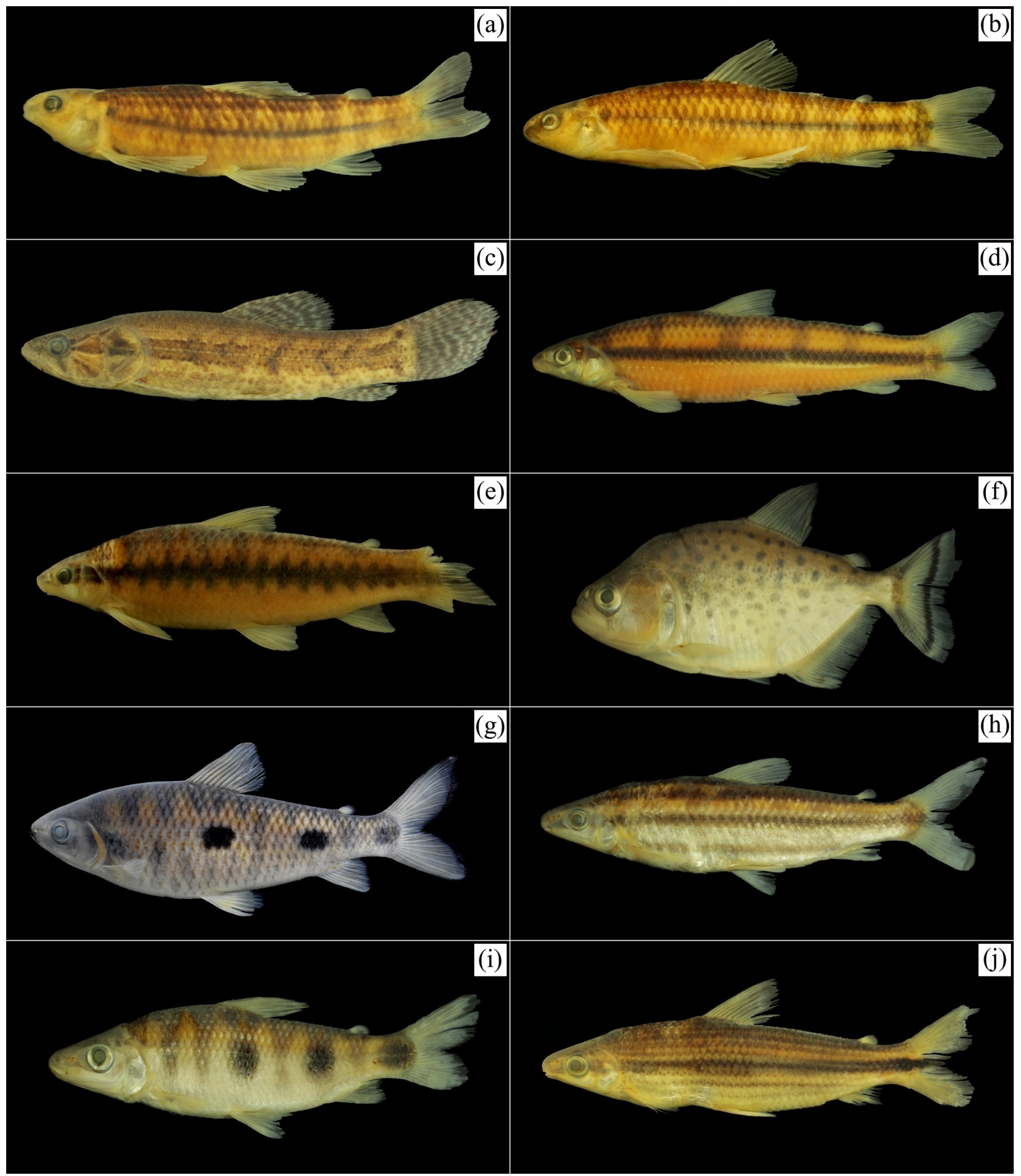

Figure 2. Some fish species (Actinopterygii) collected in the Guareí River basin: (a) Characidium gomesi, $51.5 \mathrm{~mm}$ SL; (b) Characidium zebra, $64.8 \mathrm{~mm}$ SL; (c) Hoplias malabaricus, $93.5 \mathrm{~mm}$ SL; (d) Apareiodon affinis, $89.7 \mathrm{~mm}$ SL; (e) Parodon nasus, $91.3 \mathrm{~mm}$ SL; (f) Serrasalmus maculatus, $86.7 \mathrm{~mm}$ SL; (g) Leporinus friderici, $144.9 \mathrm{~mm}$ SL; (h) Leporinus striatus, $87.1 \mathrm{~mm}$ SL; (i) Megaleporinus obtusidens, $86.2 \mathrm{~mm}$ SL; (j) Schizodon nasutus, $137.2 \mathrm{~mm}$ SL. 




Figure 3. Some fish species (Actinopterygii) collected in the Guareí River basin: (a) Cyphocharax modestus, $96.4 \mathrm{~mm}$ SL; (b) Steindachnerina insculpta, $67.9 \mathrm{~mm}$ SL; (c) Psalidodon bockmanni, $59.8 \mathrm{~mm} \mathrm{SL}$; (d) Psalidodon fasciatus, $63.1 \mathrm{~mm}$ SL; (e) Astyanax lacustris, $64.3 \mathrm{~mm}$ SL; (f) Psalidodon cf. paranae, $38.1 \mathrm{~mm}$ SL; (g) Bryconamericus aff. iheringii, $49.1 \mathrm{~mm} \mathrm{SL}$; (h) 'Cheirodon' stenodon, $29.1 \mathrm{~mm} \mathrm{SL}$; (i) Galeocharax gulo, $167.9 \mathrm{~mm}$ SL; (j) Hyphessobrycon eques, $22.1 \mathrm{~mm}$ SL. 


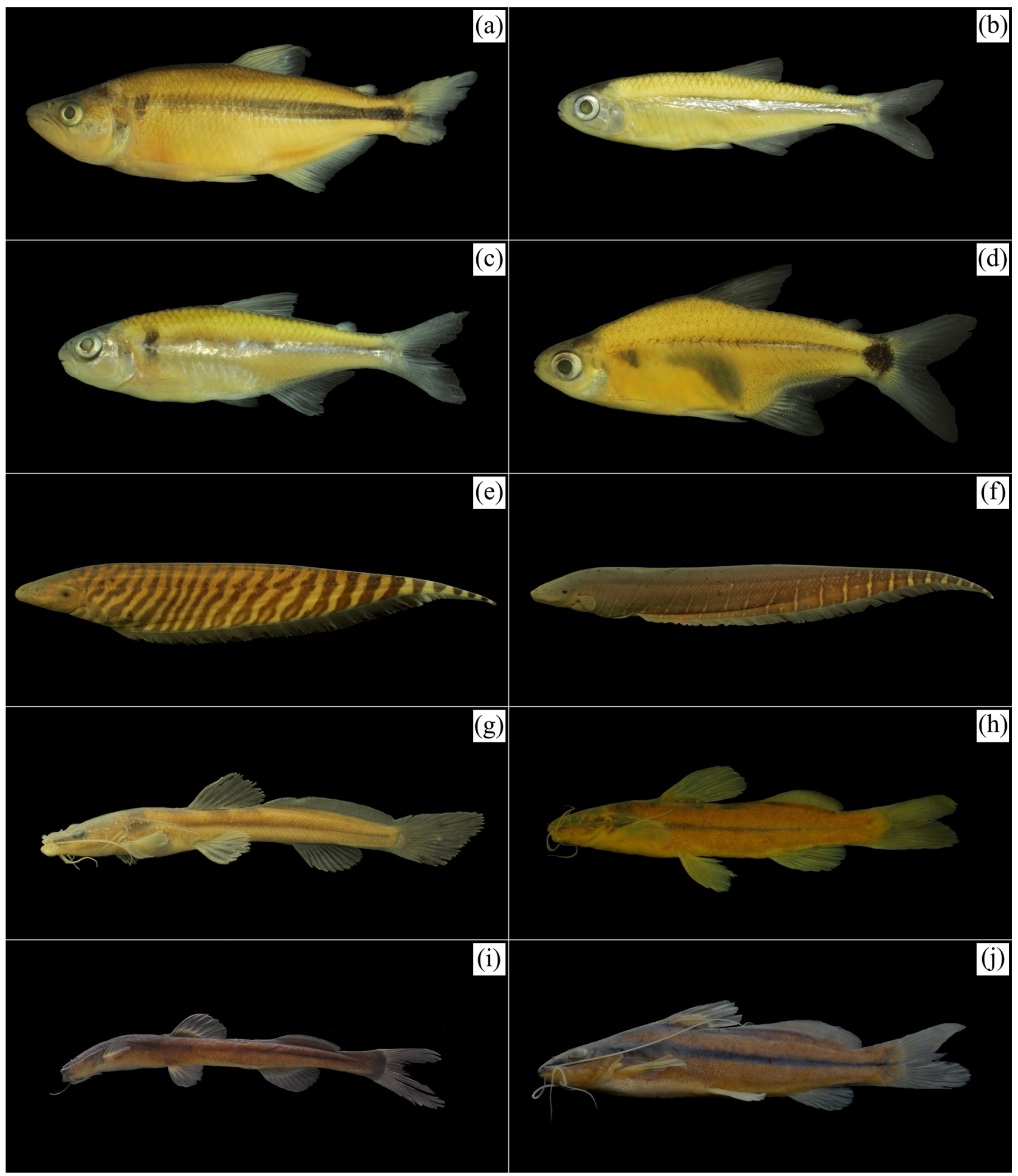

Figure 4. Some fish species (Actinopterygii) collected in the Guareí River basin: (a) Oligosarcus paranensis, $144.3 \mathrm{~mm}$ SL; (b) Piabarchus cf. stramineus, 48.1 mm SL; (c) Piabina argentea, 58.2 mm SL; (d) Serrapinnus notomelas, $29.5 \mathrm{~mm}$ SL; (e) Gymnotus carapo, $108.6 \mathrm{~mm}$ TL; (f) Gymnotus pantanal 197.2 mm TL; (g) Imparfinis borodini, $32.8 \mathrm{~mm} \mathrm{SL}$; (h) Imparfinis mirini, $60.2 \mathrm{~mm} \mathrm{SL}$; (i) Phenacorhamdia tenebrosa, $80.1 \mathrm{~mm}$ SL; (j) Pimelodella avanhandavae, $83.7 \mathrm{~mm}$ SL. 


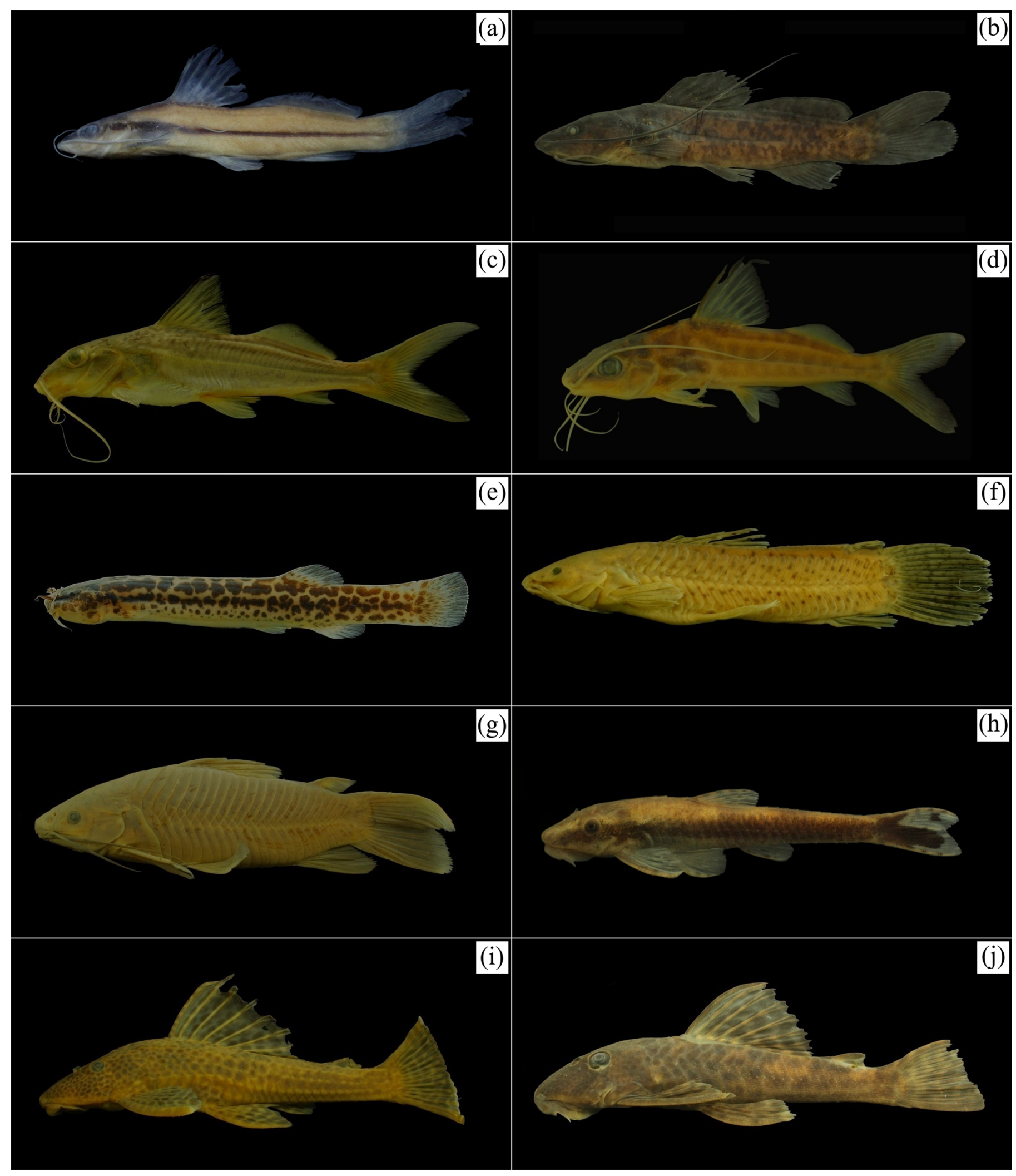

Figure 5. Some fish species (Actinopterygii) collected in the Guareí River basin: (a) Pimelodella gracilis $60.1 \mathrm{~mm}$ SL; (b) Rhamdia quelen, $47.6 \mathrm{~mm}$ SL; (c) Iheringichthys labrosus, $101.8 \mathrm{~mm}$ SL; (d) Pimelodus maculatus, $81.9 \mathrm{~mm}$ SL; (e) Cambeva guareiensis, $55.4 \mathrm{~mm}$ SL; (f) Callichthys callichthys, $56.5 \mathrm{~mm}$ SL; (g) Hoplosternum littorale, $100.8 \mathrm{~mm}$ SL; (h) Hisonotus depressicauda, $34.8 \mathrm{~mm}$ SL; (i) Hypostomus ancistroides, 141.4 mm SL; (j) Hypostomus iheringii, $93.7 \mathrm{~mm}$ SL. 


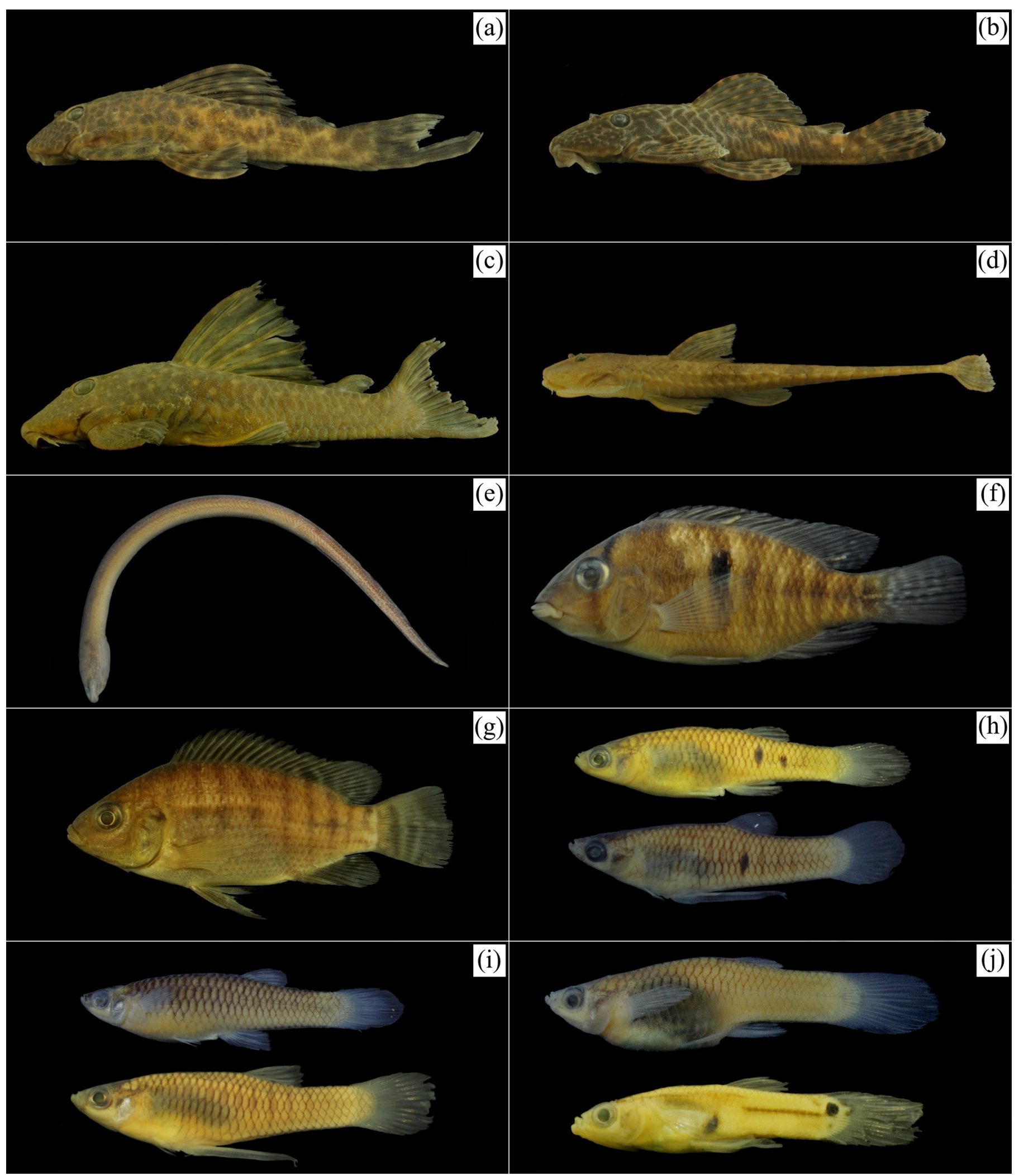

Figure 6. Some fish species (Actinopterygii) collected in the Guareí River basin: (a) Hypostomus sp. n., 81.3 mm SL; (b) Hypostomus tietensis, 81.5 mm SL; (c) Hypostomus strigaticeps, $129.4 \mathrm{~mm}$ SL; (d) Rineloricaria pentamaculata, $145.3 \mathrm{~mm}$ SL; (e) Synbranchus marmoratus, $131.7 \mathrm{~mm}$ TL; (f) Geophagus brasiliensis, $58.7 \mathrm{~mm}$ SL; (g) Oreochromis niloticus, $64.4 \mathrm{~mm} \mathrm{SL}$; (h) Phalloceros harpagos, $24.5 \mathrm{~mm}$ SL (female above), $16.3 \mathrm{~mm}$ SL (male below); (i) Phalloceros reisi, 40.7 mm SL (female above), $25.4 \mathrm{~mm}$ SL (male below); (j) Poecilia reticulata, $24.9 \mathrm{~mm}$ SL (female above), $16.4 \mathrm{~mm}$ SL (male below). 


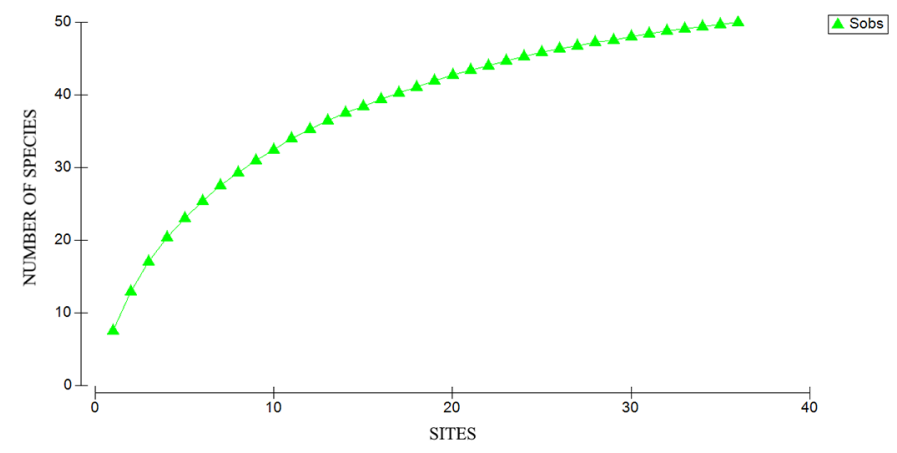

Figure 7. Species accumulation curve based on sampling effort in the Guareí River basin, Paranapanema River, São Paulo, Brazil.

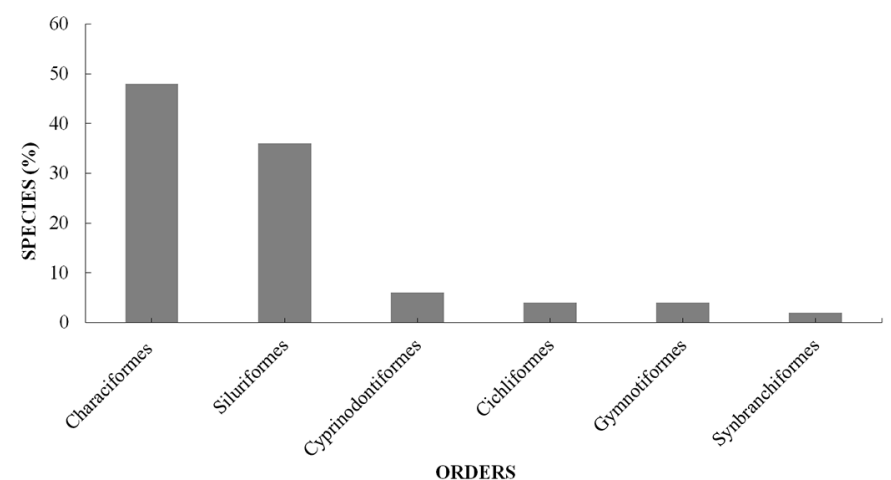

Figure 8. Species richness (\%) in each taxonomic order found in the Guarei River basin, Paranapanema River, São Paulo, Brazil.

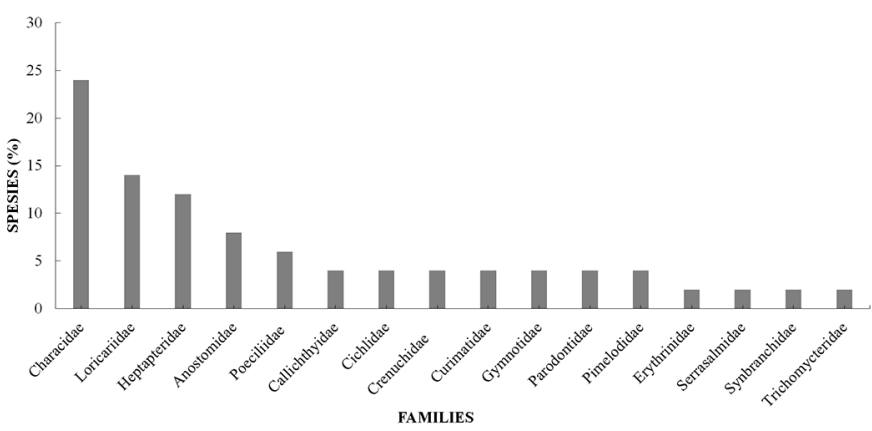

Figure 9. Species richness (\%) in each taxonomic family found in the Guarei River basin, Paranapanema River, São Paulo, Brazil.

The natural origin of the electric eel Gymnotus pantanal is uncertain. This species was described by Fernandes et al. (2005), with occurrence to the lower portion of the Paraná River, the La Plata River, and a tributary of the Amazon basin. Some authors (Júlio Júnior et al. 2009; Jarduli et al. 2020) argued that G. pantanal reached the Upper Paraná after the flooding of Sete Quedas waterfalls (after the construction of Itaipu Dam), which worked as natural barrier between the Upper and Middle Paraná basins. It is unlikely, however, that the loss of Sete Quedas caused this introduction in the Guareí River basin, considering the distance and the number of dams along the Paranapanema River (cf. Pelicice et al. 2018), most of them built before Itaipu (e.g., Jurumirim). Alternatively, sport fishing has been an important vector causing the introduction of non-native species in Brazilian waters (e.g., Daga et al. 2016; Pereira \& Vitule 2019), and could be responsible for the introduction of G. pantanal as live baits (Jarduli et al. 2020).
However, it would need repeated events of introduction in the Guareí River basin, which seems unlikely. Therefore, the status of G. pantanal in the Guareí River basin deserves further examination.

We recorded three "migratory" species (sensu Vazzoler 1996: p. 96-97), Leporinus friderici, Megaleporinus obtusidens (Valenciennes 1837), and Pimelodus maculatus Lacepède 1803. These fishes provide important income for fishermen living in the Angatuba region (Novaes \& Carvalho 2009) and other cities along the Paranapanema River. Other migratory fishes are found in the Jurumirim Reservoir and tributaries, such as Prochilodus lineatus (Valenciennes 1837) and Salminus hilarii Valenciennes 1850 (Kurchevski \& Carvalho 2014; Nobile et al. 2019). They may occur in the Guareí River basin, particularly in the main channel, either year-round or seasonally, using this tributary as a feeding ground or spawning site.

In the description of Phalloceros reisi, Lucinda (2008) recorded the species for the upper Paraná River system, but only for waterbodies of the Tietê River basin. Cetra et al. (2012) were probably the first to record this species in the Paranapanema River basin. Later, other authors reported its presence in different waterbodies of the same watershed (Cerqueira et al. 2016; Cetra et al. 2016; Peressin et al. 2018). In this study, we found $P$. reisi in 12 sites, expanding its range in the Paranapanema River basin.

We also found two undescribed taxa, Bryconamericus aff. iheringii and Hypostomus sp. n. Both had already been captured in areas close to the Guareí River basin (Kurchevski \& Carvalho 2014), and the present work expanded their known range. Herein, we just mention that the description of Hypostomus sp. $\mathrm{n}$. is in progress (C. H. Zawadzki, pers. comm.). Cambeva guareiensis Katz \& Costa 2020, a recently described species, is known only from streams in the Guareí River Guareí River basin (Katz \& Costa 2020; this work). As observed for other species of the genus (e.g., Cambeva diabola Bockmann, Casatti, de Pinna 2004), it may have a wider distribution.

The identification of some species was uncertain. Psalidodon cf. paranae (Eigenmann 1914) integrates the complex 'Astyanax' scabripinnis, which presents similar morphology (Bertaco \& Lucena 2006), including undescribed species (e.g., Azevedo-Santos et al. 2019). Until a better definition of $P$. paranae, we treat the form captured in the Guareí River basin with caution. On the other hand, Piabarchus cf. stramineus (Eigenmann 1908) shows no trace of chromatophores in the humeral region, as reported by Eigenmann (1908) in the original description of this species. It is not known whether this character represents intraspecific variation, so we also treat its identification with caution.

\section{Conclusion}

This is the most comprehensive survey on fish diversity in the Guareí River basin. We recorded 50 species, most of which are native to the watershed, including migratory fishes and some taxa unknown to science. Fish diversity may be greater, considering the trend observed in the rarefaction curve. These results emphasize the role of tributaries as hotspots of fish biodiversity in impounded areas, with an important function in reservoirs that support fishing activity, such as the Jurumirim Reservoir. Therefore, conservation efforts must be directed to the Guareí River basin, especially to protect its tributaries. 


\section{Supplementary Material}

The following online material is available for this article:

Figure S1 - Individuals (in life) of 15 species collected from the Guareí River basin: (a) Characidium gomesi; (b) Hoplias malabaricus; (c) Psalidodon bockmanni; (d) Astyanax lacustris; (e) Bryconamericus aff. iheringii; (f) Serrapinnus notomelas; (g) Gymnotus carapo; (h) Phenacorhamdia tenebrosa; (i) Rhamdia quelen; (j) Callichthys callichthys; (k) Hisonotus depressicauda; (1) Rineloricaria pentamaculata; (m) Geophagus brasiliensis; (n) Oreochromis niloticus; (o) Phalloceros reisi.

Table S1 - Species (Actinopterygii) collected and their abundance in each site (1 to 18) of the Guareí River basin, São Paulo, Brazil.

Table S2 - Species (Actinopterygii) collected and their abundance in each site (19 to 36) of the Guareí River basin, São Paulo, Brazil.

\section{Acknowledgements}

We are grateful to Hamilton A. Rodrigues (UNESP), Paula N. Coelho (UNESP), Vinícius São Pedro (UFSCar) and EcoRoad team, for assistance during collection activities, and to Carla S. Pavanelli (NUP), Claudio Oliveira (LBP), Flávio A. Bockmann (LIRP), Paulo A. Buckup (MNRJ), Paulo H. F. Lucinda (UNT), and Francisco Langeani (DZSJRP), for assistance in depositing voucher specimens in collections. We are also grateful to Jack M. Craig (ULL), for confirming the determination of some gimnotids, and to Cláudio H. Zawadzki (UEM), for the identification of some loricariids. We thank Jessica Colavite (UNESP), for providing the camera (Figures 2-6), and Isabel M. Soares (UNESP), for technical support with some photographs. Geovana S. Andrade (UFT) and Carolina G. Santiago (UFT) helped with the organization of some vouchers. We wish thank Andréa Bialetzki (UEM), Reinaldo J. Castro (UFSCar), André B. Nobile (UNESP), and Angelo A. Agostinho (UEM), for comments and corrections - which were valuable for the improvement of this manuscript. To the three anonymous reviewers, for the comments and suggestions. This study was possible due to the scholarship granted by the Coordenação de Aperfeiçoamento de Pessoal de Nível Superior (CAPES - 001) for Valter M. Azevedo-Santos. CNPq provided a research grant for Fernando M. Pelicice.

\section{Author Contributions}

Valter M. Azevedo-Santos idealized the work, collected and identified species, provided ideas, wrote the first version of the manuscript.

Fernando M. Pelicice provided ideas and collaborated with the writing process.

Raoul Henry provided ideas and collaborated with the writing process.

\section{Conflicts of Interest}

None.

\section{References}

AgOstinHO, A.A. \& JÚLIO-JR. H.F. 1999. Peixes da bacia do Alto rio Paraná. In Estudos ecológicos de comunidades de peixes tropicais (R.H. Lowe-McConnell). Edusp, São Paulo, p. 374-400.

AGOSTINHO, A. A., PELICICE, F. M. PETRY, A. C., GOMES, L. C. \& JÚLIO JR., H. F. 2007. Fish diversity in the upper Paraná River basin: habitats, fisheries, management and conservation. Aquat. Ecosyst. Health Manag. 10(2): 174-186. https://doi.org/10.1080/14634980701341719
AGOSTINHO, A.A., PELICICE, F.M. \& GOMES, L. C. 2008. Dams and the fish fauna of the Neotropical region: Impacts and management related to diversity and fisheries. Braz. J. Biol. 68 (4): 1119-1132. http://dx.doi. org/10.1590/S1519-69842008000500019

ALVES, G.H.Z., TÓFOLI, R.M., GANASSIN, M.J.M. \& HAHN, N.S. 2016. Diet of Poecilia reticulata Peters, 1959 in streams from Paraná River basin: influence of the urbanization. Acta Sci. Biol. Sci. 38: 313-318. https://doi. org/10.4025/actascibiolsci.v38i3.29881

ARAÚJO, M.I., DELARIVA, R.L., BONATO, K.O. \& SILVA, J.C. 2011. Fishes in first order stream in Ivaí River drainage basin, upper Paraná River Basin, Paraná state, Brazil. Check List 7: 774-777.

AZEVEDO-SANTOS, V.M., RIGOLIN-SÁ, O. \& PELICICE, F.M. 2011. Growing, losing or introducing? Cage aquaculture as a vector for the introduction of non-native fish in in Furnas Reservoir, Minas Gerais, Brazil. Neotrop. Ichthyol. 9(4), 915-919. http://dx.doi.org/10.1590/S167962252011000400024

AZEVEDO-SANTOS, V.M., BRAMBILlA, E.M., COELHO, P.N. \& BRITTON, J.R. 2018. Length-weight relationships of two catfish species from the Guareí River basin, São Paulo, Brazil. J. Appl. Ichthyol. 34: 1019 - 1020. https://doi.org/10.1111/jai.13648

AZEVEDO-SANTOS, V.M., BRITSKI, H.A., OLIVEIRA, C. \& BENINE, R.C. 2019. Ichthyofauna of streams of the Rio Sapucaí basin, upper Rio Paraná system, Minas Gerais, Brazil. Biota Neotrop. 19: e20180617. http://dx.doi. org/10.1590/1676-0611-bn-2018-0617

AZEVEDO-SANTOS, V.M., VITULE, J.R.S., GARCÍA-BERTHOU, E., PELICICE, F.M. \& SIMBERLOFF, D. 2016. Misguided strategy for mosquito control. Science 351:675. https://doi.org/10.1126/ science.351.6274.675

BERTACO, V.A. \& LUCENA, C.A.S. 2006. Two new species of Astyanax (Ostariophysi: Characiformes: Characidae) from eastern Brazil, with a synopsis of the Astyanax scabripinnis species complex. Neotrop. Ichthyol. 4, 53-60. http://dx.doi.org/10.1590/S1679-62252006000100004

BRANDÃO, H., VIDOTTO-MAGNONI, A.P., RAMOS, I.P. \& CARVALHO, E.D. 2009. Assessment of the ichthyofauna in stretches under the influence of Salto Grande Reservoir (Middle Paranapanema River, SP/PR, Brazil). Acta Limnol. Bras. 21(4):451-63.

BRITTO, S.G.C. \& CARVALHO, E.D. 2006. Ecological attributes of fish fauna in the Taquaruçu Reservoir, Paranapanema River (Upper Paraná, Brazil): composition and spatial distribution. Acta Limnol. Bras. 18(4):377-88.

CARVALHO, F.R. \& LANGEANI, F. 2013. Hyphessobrycon uaiso: new characid fish from the rio Grande, upper rio Paraná basin, Minas Gerais State (Ostariophysi: Characidae), with a brief comment about some types of Hyphessobrycon. Neotrop. Ichthyol. 11(3): 525-536. http://dx.doi. org/10.1590/S1679-62252013000300006

CASIMIRO, A.C.R., GARCIA, D.A.Z., VIDOTTO-MAGNONI, A.P., BRITTON, J.R., AGOSTINHO, A.A., ALMEIDA, F.S. \& ORSI, M.L. 2018. Escapes of non-native fish from flooded aquaculture facilities: the case of Paranapanema River, southern Brazil. Zool. 35:1-6. http://dx.doi. org/10.3897/zoologia.35.e14638

CASTRO, R.J., FORESTI, F. CARVALHO, E.D. 2003a. Composição e abundância da ictiofauna na zona litorânea de um tributário, na zona de sua desembocadura no reservatório de Jurumirim, Estado de São Paulo, Brasil. Acta Sci. Biol. Sci. 25: 63-70.

CASTRO, R.M.C., CASATTI, L., SANTOS, H.F., FERREIRA, K.M., RIBEIRO, A.C., BENINE, R.C., DARDIS, G.Z.P., MELO, A.L.A., STOPLIGLIA, R., ABREU, T.X., BOCKMANN, F.A., CARVALHO, M., GIBRAN, F.Z. \& LIMA, F.C.T. 2003b. Estrutura e composição da ictiofauna de riachos do Rio Paranapanema, Sudeste e Sul do Brasil. Biota Neotrop. 3(1): 1-14.

CAVALLI, D., FROTA, A., LIRA, A. D., GUBIANI, E. A., MARGARIDO, V. P. \& GRAÇA, W. J. 2018. Update on the ichthyofauna of the Piquiri River basin, Paraná, Brazil: a conservation priority area. Biota Neotrop. 18(2): e20170350. http://dx.doi.org/10.1590/1676-0611-BN-2017-0350

CERQUEIRA, V.L.A., CARVALHO, M.P., ALMEIDA, R.S., FERREIRA, F.C., CETRA, M. \& SMITH, W.S. 2016. Stream fish fauna from the tributaries of the upper Itapetininga River, upper Paranapanema River basin, state of São Paulo, Brazil. Check List 12(2): 1879. http://dx.doi.org/10.15560/12.2.1879 
CETRA, M., BARRELLA, W.A., LANGEANI NETO, F., MARTINS, A.G., MELLO, B.J. \& ALMEIDA, R.S. 2012. Fish fauna of headwater streams that cross the Atlantic Forest of south São Paulo state. Check List 8(3):421425. http://dx.doi.org/10.15560/8.3.421

CETRA, M., MATTOX, G.M.T., FERREIRA, F.C., GUINATO, R.B., SILVA, F.V. \& PEDROSA, M. 2016. Headwater stream fish fauna from the Upper Paranapanema River basin. Biota Neotrop. 16(3): e20150145. http://dx.doi. org/10.1590/1676-0611-BN-2015-0145

CIONEK, V.M., SACRAMENTO, P.A., ZANATTA, N., OTA, R.P., CORBETTA, D.F. \& BENEDITO, E. 2012. Fishes from first order streams of lower Paranapanema and Ivaí rivers, upper Paraná River basin, Paraná, Brazil. Check List 8(6): 1158-1162. http://dx.doi.org/10.15560/8.6.1158

CLARKE, K.R. \& WARWICK, R.M. 2001. Change in Marine Communities: An Approach to Statistical Analysis and Interpretation. 2nd Edition, PRIMER-E, Ltd., Plymouth Marine Laboratory, Plymouth.

CUNICO, A.M., GRAÇA, W.J., AGOSTINHO, A.A. DOMINGUES, W.M. \& LATINI, J.D. 2009. Fish, Maringá urban streams, Pirapó river drainage, upper Paraná river basin, Paraná State, Brazil. Check List 5: 273-280.

DAGA, V.S., DEBONA, T., ABILHOA, V., GUBIANI, É.A. \& VITULE, J.R.S. 2016. Non-native fish invasions of a Neotropical ecoregion with high endemism: a review of the Iguaçu River. Aquat. Invasions 11(2):209-223. http://dx.doi.org/10.3391/ai.2016.11.2.10

DAGOSTA, F.C.P. \& DE PINNA, M. 2019. The Fishes of the Amazon: Distribution and biogeographical patterns, with a comprehensive list of species. B. Am. Mus. Nat. Hist. 2019(431):1-163. https://doi. org/10.1206/0003-0090.431.1.1

DIAS, A.M. \& TEJERINA-GARRO, F. L. 2010. Changes in the structure of fish assemblages in streams along an undisturbed-impacted gradient, upper Paraná River basin, Central Brazil. Neotrop. Ichthyol. 8: 587-598. https:// doi.org/10.1590/S1679-62252010000300003

DIAS, M. S., FARIA, I. F., GUARIDO, P. C. P., TERESA, F. B., AQUINO, P.D. P.U., \& QUIMBAYO, J. P. 2020. Historical distribution and current drivers of guppy occurrence in J. Fish Biol. 96 (4): 877-885. https://doi.org/10.1111/jfb.14271

DONASCIMIENTO, C., HERRERA-COLLAZOS, E.E., HERRERA-R, G.A., ORTEGA-LARA, A., VILLA-NAVARRO, F.A., USMA-OVIEDO, J.S. \& MALDONADO-OCAMPO, J.A. 2017. Checklist of the freshwater fishes of Colombia: a Darwin Core alternative to the updating problem. ZooKeys 708: 25-138. https://doi.org/10.3897/zookeys.708.13897

ESGUÍCERO, A. L. H. \& ARCIFA, M. S. 2011. The fish fauna of the JacaréGuaçu River basin, Upper Paraná River basin. Biota Neotrop. 11(1): 103113. https://doi.org/10.1590/S1676-06032011000100010

EIGENMANN, C. H. 1908. Preliminary descriptions of new genera and species of tetragonopterid characins. (Zoölogical Results of the Thayer Brazilian expedition.). Bull. Mus. Comp. Zool. 52: 91-106.

FERNANDES, F. M. C., ALBERT, J. S., DANIEL-SILVA, M. F. Z., LOPES, C. E., CRAMPTON, W. G. R. \& ALMEIDA-TOLEDO, L. F. 2005. Anew Gymnotus (Teleostei: Gymnotiformes: Gymnotidae) from the Pantanal Matogrossense of Brazil and adjacent drainages: continued documentation of a cryptic fauna. Zootaxa 933: 1-14. http://dx.doi.org/10.11646/zootaxa.933.1.1

FRICKE, R., ESCHMEYER, W. N. \& VAN DER LAAN, R. (eds) 2020a. CATALOG OF FISHES: GENERA, SPECIES, REFERENCES. (http:// researcharchive.calacademy.org/research/ichthyology/catalog/fishcatmain. asp).Electronic version accessed 08/01/2019.

FRICKE, R., ESCHMEYER, W. N. \& FONG, J. D. 2020b. SPECIES BY FAMILY/SUBFAMILY. (http://researcharchive.calacademy.org/research/ ichthyology/catalog/SpeciesByFamily.asp). Electronic version accessed 08/01/2019 [Recalculated with each new version; based on current literature, this provides all available species names, valid species, and species described in the last 10 years by family/subfamily.].

FROTA, A., OTA, R. R., DEPRÁ, G. C., GANASSIN, M. J. M. \& DA GRAÇA, W. J. 2020. A new inventory for fishes of headwater streams from the rio das Cinzas and rio Itararé basins, rio Paranapanema system, Paraná, Brazil. Biota Neotrop. 20(1): e20190833. http://dx.doi.org/10.1590/1676-0611BN-2019-0833
FULAN, J.A. HENRY, R. \& DAVANSO, R. 2012. Os efeitos da ação antrópica sobre a distribuição de macroinvertebrados no Rio Guareí, São Paulo. Estudos de Biologia 34: 51-56.

GARCIA, D. A. Z., BRITTON, J. R., VIDOTTO-MAGNONI, A. P., \& ORSI, M. L. 2018. Introductions of non-native fishes into a heavily modified river: rates, patterns and management issues in the Paranapanema River (Upper Paraná ecoregion, Brazil). Biol. Inv. 20(5): 1229-1241.

HENRY, R. \& GOUVEIA, L. 1993. Os fluxos de nutrientes e seston em cursos de água do Alto Paranapanema (São Paulo) - sua relação com o uso de solo e morfologia das bacias de drenagem. An. Acad. Brasil. Ci. 65: 439-451.

HOFFMANN, A.C., ORSI, M.L. \& SHIBATTA, O.A. 2005. Diversidade de peixes do reservatório da UHE Escola Engenharia Mackenzie (Capivara), rio Paranapanema, bacia do alto rio Paraná, Brasil, e a importância dos grandes tributários na sua manutenção. Iheringia Sér. Zool. 95(3):319-325.

ICMBio. 2018. INSTITUTO CHICO MENDES DE CONSERVAÇÃO DA BIODIVERSIDADE - Livro Vermelho da Fauna Brasileira Ameaçada de Extinção: Volume VI - Peixes / -- 1. ed. -- Brasília, DF: ICMBio/MMA, 2018.7 v.: il.. Disponível em: http://www.icmbio.gov.br/portal/component/ content/article/10187

JARDULI, L.R., GARCIA, D.A.Z., VIDOTTO-MAGNONI, A.P., CASIMIRO, A.C.R., VIANNA, N.C., ALMEIDA, F.S., JEREP, F.C. \& ORSI, M.L. 2020. Fish fauna from the Paranapanema River basin, Brazil. Biota Neotrop. 20: e20180707. http://dx.doi.org/10.1590/1676-0611-bn-2018-0707

JÚLIO JÚNIOR, H.F., DEI TÓS, C., AGOSTINHO, A.A. \& PAVANELLI, C.S. 2009. A massive invasion of fish species after eliminating a natural barrier in the upper rio Paraná basin. Neotrop. Ichthyol. 7(4):709-718. http://dx.doi. org/10.1590/S1679-62252009000400021

KATZ, A.M. \& COSTA, W.J.E.M. 2020. A new species of the catfish genus Cambeva from the Paranapanema river drainage, southeastern Brazil (Siluriformes: Trichomycteridae). Trop. Zool. 33: 2-13. https://doi. org/10.4081/tz.2020.63

KURCHEVSKI, G. \& CARVALHO, E.D. 2014. Os peixes da represa de Jurumirim: revisão temporal de estudos independentes. In: Henry, R. (Org.). Represa de Jurumirim: ecologia, modelagem e aspectos sociais. 1ed.Ribeirão Preto: Holos, 2014, v., p. 325-342.

LANGEANI, F., CASTRO, R.M.C., OYAKAWA, O.T., SHIBATTA, O.A., PAVANELLI, C.S. \& CASATTI, L. 2007. Diversidade da ictiofauna do Alto Rio Paraná: Composição atual e perspectivas futuras. Biota Neotrop. 7 (3): bn03407032007. http://dx.doi.org/10.1590/S1676-06032007000300020

LOURES, R.C. \& POMPEU, P.S. 2018. Long-term study of reservoir cascade in south-eastern Brazil reveals spatio-temporal gradient in fish assemblages. Mar. Freshw. Res. 69(12): 1983-1994. http://doi.org/10.1071/MF18109

LEITE, I., FOGAÇA, C.A., MATOS, D.R.M., FÉLIX, E.S., GOMES, K.F., OLIVEIRA, R.F., HONÓRIO, R.K.A. 2012. A bacia de drenagem, a geomorfologia, os usos do solo, a cobertura vegetal, a precipitação e o canal fluvial do rio Guareí, pages 31-50. In: HENRY, R. O diagnóstico da qualidade das águas do rio Guareí (Angatuba, SP): uma cooperação ensino superior - educação básica. - Botucatu: FUNDIBIO, 155 pp.

LIMA, F.P., NOBILE, A.B., FREITAS-SOUZA, D., CARVALHO, E.D. \& VIDOTTO-MAGNONI, A.P. 2016. Feeding ecology of Rhinodoras dorbignyi (Kner, 1855) (Siluriformes: Doradidae) in the Paranapanema River, SP, Brazil. Biotemas 29 (1): 67-73. https://doi.org/10.5007/21757925.2016v29n1p67

LIMA, F.P., NOBILE, A.B., FREITAS-SOUZA, D., CARVALHO, E.D. \& VIDOTTO-MAGNONI, A.P. 2018. Can dams affect the trophic structure of ichthyofauna? A long-term effects in the Neotropical region. Iheringia, Sér. Zool. 108: e2018030. http://dx.doi.org/10.1590/1678-4766e2018030

LITZ, T.O. \& KOERBER, S. 2014. Check List of the Freshwater Fishes of Uruguay (CLOFF-UY). Ichthyol. Contrib. Pec. Crioll. 28: 1-40.

LUCINDA, P.H.F. 2008. Systematics and biogeography of the genus Phalloceros Eigenmann, 1907 (Cyprinodontiformes: Poeciliidae: Poeciliinae), with the description of twenty-one new species. Neotrop. Ichthyol. 6(2):113-58. http://dx.doi.org/10.1590/S1679-62252008000200001 
MARQUES, H., DIAS, J.H.P., PERBICHE-NEVES, G., KASHIWAQUI, E.A.L. \& RAMOS, I.P. 2018. Importance of dam-free tributaries for conserving fish biodiversity in Neotropical reservoirs. Biol. Conserv. 224:347-354. https:// doi.org/10.1016/j.biocon.2018.05.027

MANOEL, P. S. \& UIEDA, V.S. 2018. Effect of the riparian vegetation removal on the trophic network of Neotropical stream fish assemblage. Rev. Ambient. Água 13: e2088. http://dx.doi.org/10.4136/ambi-agua.2088

MIRANDE, J. M. \& KOERBER, S. 2015. Checklist of the freshwater fishes of Argentina (CLOFFAR). Ichthyol. Contrib. Pec. Crioll. 36: 1-68.

NOBILE, A. B., FREITAS-SOUZA, D. LIMA, F. P., BAYONA PEREZ, I. L. BRITTO, S. G. C., RAMOS, I. P. 2017. Occurrence of Misgurnus anguillicaudatus (Cantor, 1842) (Cobitidae) in the Taquari River, Upper Paraná Basin, Brazil. J. Appl. Ichthyol. 33: 527-529.

NOBILE, A.B., FREITAS-SOUZA, D., LIMA, F.P., QUEIROZ, J., BAYONAPEREZ, I.L., CARVALHO, E.D. \& RAMOS, I.P. 2019. Damming and seasonality as modulators of fish community structure in a small tributary. Ecol. Freshw. Fish. 28: 563-572. https://doi.org/10.1111/eff.12475

NOVAES, J.L.C. \& CARVALHO, E.D. 2009. Recursos pesqueiros oriundos da pesca artesanal no reservatório de Jurumirim, Rio Paranapanema, Alto Paraná, Brasil. Bol. Inst. Pesca 35: 553-565.

NUNES, D.M.F., MAGALHÃES, A.L.B., WEBER, A.A., GOMES, R.Z., NORMANDO, F.T., SANTIAGO, K.B., RIZZO, E. \& BAZZOLI, N. 2015. Influence of a large dam and importance of an undammed tributary on the reproductive ecology of the threatened fish matrinxã Brycon orthotaenia Günther, 1864 (Characiformes: Bryconidae) in southeastern Brazil. Neotrop. Ichthyol. 13(2): 317-324

ORSI, M.L. \& AGOSTINHO, A.A. 1999. Introdução de espécies de peixes por escapes acidentais de tanques de cultivo em rios da bacia do rio Paraná, Brasil. Rev. Bras. Zool. 16(2):557-560.

OTA, R.R., DEPRÁ, G.D., GRAÇA, W.J. \& PAVANELLI, C.S. 2018. Peixes da planície de inundação do alto rio Paraná e áreas adjacentes: revised, annotated and updated. Neotrop. Ichthyol. 16(2): e170094. http://dx.doi. org/10.1590/1982-0224-20170094

PAGOTTO, J.P.A., VERÍSSIMO, S., GOULART, E., MISE, F.T. 2012. Fishes (Osteichthyes: Actinopterygii) from the Pirapó River drainage, upper Paraná River basin, Paraná state, Brazil. Check List 8(3): 463-468.

PANARELLI, E. A., NOGUEIRA, M. G. \& HENRY, R. 2001. Short-term variability of copepod abundance in Jurumirim Reservoir, São Paulo, Brazil. Braz. J. Biol. 61: 577-598. http://dx.doi.org/10.1590/S151969842001000400007

PELICICE, F.M. \& AGOSTINHO, A.A. 2008. Fish-passage facilities as ecological traps in large Neotropical rivers. Conserv. Biol. 1(22):180-88.

PELICICE, F.M., AZEVEDO-SANTOS, V.M., VITULE, J.R.S., ORSI, M.L., LIMA-JUNIOR, D.P., MAGALHÃES, A.L.B., POMPEU, P.S., PETRERE JR, M. \& AGOSTINHO, A.A. 2017. Neotropical freshwater fishes imperilled by unsustainable policies. Fish Fish. 18 (6):1119-1133. https:// doi.org/10.1111/faf.12228

PELICICE, F.M., AZEVEDO-SANTOS, V.M., ESGUÍCERO, A.L.H., AGOSTINHO, A.A. \& ARCIFA, M.S. 2018. Fish diversity in the cascade of reservoirs along the Paranapanema River, southeast Brazil. Neotrop. Ichthyol. 16(2):e170150. http://dx.doi.org/10.1590/1982-0224-20170150

PERESSIN, A., GONÇALVES, C. S., \& CETRA, M. 2018. Ichthyofauna diet changes in response to urbanization: the case of upper Paranapanema River basin (Brazil). Urban Ecosyst. 21, 795-803. https://doi.org/10.1007/ s11252-018-0755-9
PEREIRA, F.W. \& VITULE, J.R.S. 2019. The largemouth bass Micropterus salmoides (Lacepède, 1802): impacts of a powerful freshwater fish predator outside of its native range. Rev. Fish. Biol. Fisher. 29: 639-652. https://doi. org/10.1007/s11160-019-09570-2

PETESSE, M.L. \& PETRERE, M. JR. 2012. Tendency towards homogenization in fish assemblages in the cascade reservoir system of the Tietê river basin, Brazil. Ecol. Eng. 48(1):109-16. http://doi.org/10.1016/j.ecoleng.2011.06.033

QUEIROZ-SOUSA, J., KEITH, S.A., DAVID, G.S., BRANDÃO, H., NOBILE, A.B., PAES, J.V.K., SOUTO, A.C., LIMA, F.P., SILVA, R.J., HENRY, R, \& RICHARDSON, K. 2019. Species richness and functional structure of fish assemblages in three freshwater habitats: effects of environmental factors and management. J. Fish. Biol. 95: 1125-1136. https://doi.org/10.1111/jfb.14109

SANTOS, A. C.; GONCALVES, C. C. \& CARVALHO, F.R. 2017. Ichthyofauna of the "Cachoeira de São Roberto" and fishes of lower Preto River, upper Paraná River basin, Brazil. Biota Neotrop. 17(1): e20160196. https://doi. org/10.1590/1676-0611-bn-2016-0196

SARTORI, L.P., NOGUEIRA, M.G. HENRY, R. \& MORETTO, E.M. 2009 Zooplankton fluctuations in Jurumirim Reservoir (São Paulo, Brazil): a three-year study. Braz. J. Biol. 69: 1-18. http://dx.doi.org/10.1590/S151969842009000100002

SCHUBART, O. 1964. Duas novas espécies de peixe da família Pimelodidae do Rio Mogi Guaçu (Pisces, Nematognathi). Bol. Mus. Nac., Zool. 244:1-22.

SEABRA, S., PRADO, C.H.O.P., CAVALHEIRO, E.A., LEITE, G.O., COSTA, G.T., BASILE, J.P.V., JUNIOR, J.R.P., RODRIGUES, J., OLIVEIRA, L.P., FEREIRA, P.M., SOUTO, A.C., VIDOTTO-MAGNONI, A.P. \& SILVA, C.V. 2012. Fauna associada às plantas aquáticas em ambientes lacustres marginais ao rio Guareí, pages 99-115. In: HENRY, R. O diagnóstico da qualidade das águas do rio Guareí (Angatuba, SP): uma cooperação ensino superior - educação básica. - Botucatu: FUNDIBIO, 155 pp.

SHERMAN, G.E., T. SUTTON, R. BLAZEK, S. HOLL, O. DASSAU, B. MORELY, T. MITCHELL, AND L. LUTHMAN. 2012. Quantum GIS User Guide. Version 1.8 "Wroclaw". http://download.osgeo.org/qgis/doc/manual/ qgis-1.8.0_user_guide_en.pdf

SILVA, P.S. MAKRAKIS, M. C., MIRANDA, L. E., MAKRAKIS, S., L. ASSUMPÇÃO, L., PAULA, S., DIAS, J. H. P. \& MARQUES, H. 2015. Importance of Reservoir Tributaries to Spawning of Migratory Fish in the Upper Paraná River. River Res. Applic. 31: 313-322. https://doi.org/10.1002/rra.2755

STRAHLER, A. N. 1954. Quantitative geomorphology of erosional landscapes, G.-R. $19^{\text {th }}$ Intern. Geol. C//IIf., Algiers, 1952, sec. 13, pt. 3, pp. 341-354.

VAZZOLER, A.E.A. M. 1996. Biologia da reprodução de peixes teleósteos: teoria e prática / Anna Emília Amato de Moraes Vazzoler; Apresentação de Paulo de Tarso da Cunha Chaves -- Maringá: EDUEM ; São Paulo : SBI, 1996. 169 p.: il.

VICENTIN, W., FERREIRA, F.S. \& SUAREZ, Y. R. 2019. Ichthyofauna of lotic environments in the Ivinhema river basin, upper Paraná river, Mato Grosso do Sul state, Brazil. Biota Neotrop.19: e20190735. http://dx.doi. org/10.1590/1676-0611-bn-2019-0735

VIDOTTO-MAGNONI, A.P., GARCIA, D.A.Z., COSTA, A.D.A., SOUZA, J.G., YABU, M.H.S., ALMEIDA, F.S. \& ORSI, M.L. 2015. Ichthyofauna of streams of the Lower Paranapanema River basin, state of Paraná, Brazil. Check List 11(5): 1756. http://dx.doi.org/10.15560/11.5.1756

Received: $28 / 04 / 2020$

Revised: $11 / 07 / 2020$

Accepted: 16/07/2020

Published online: 19/08/2020 